\title{
Jockeying Jony: The Politics of Horse-Racing and Regional Identity in The Humorous Magistrate
}

In their respective treatments of the amateur household play The Humorous Magistrate, Mary Polito, Jean-Sébastien Windle, and Margaret Jane Kidnie have noted several significant differences between the two extant manuscript versions. ${ }^{1}$ In addition to lacking the prologue and epilogue that appear in the Arbury 414 version (itself heavily revised), the copy purchased by Edgar Osborne omits one character entirely, a figure described by Polito and Windle as 'Scottish Jony, a horseman'. ${ }^{2}$ This omission entails the removal of hundreds of lines; none of the character's speeches are reallocated to other characters, nor are the dialogues in which he takes part reproduced even partially in the later copy's version of the play.

As with any apparent omission or emendation in two versions of any playtext, the omission of Jony raises questions about the agent or agents responsible for the differences we detect; the differences themselves likewise invite consideration of the impact of such lacunae on the plays' plot and thematic content. Moreover, much like the variants found among printed plays produced and licensed for performance at the public theatres, the differences between the Arbury and Osborne copies encourage us to examine social and historical contexts as well as other literary works as factors that may have occasioned variants in the manuscripts. Polito and Windle have presented convincing cases for dating each manuscript, establishing the Arbury copy's composition between 1632 and 1637, and the Osborne's composition shortly after $1640 .{ }^{3}$ The range of likely dates for both manuscripts locates the composition and revision of the play within a period of escalating conflict between England and its neighbour to the north and growing discontent between subject and crown within England itself.

Because the play offers two examples of amateur household drama in manuscript form, Jony's presence and absence may also provide insight into the lives of English subjects in the country in those years. Jony's character is 
configured in the Arbury copy of the play primarily in brief exchanges with his master, Wild, a young man whose recreational pursuits involve riding, racing, and wagering on horses. Jony apparently cares for and prepares the horses for riding and racing and thus his lines not only provide accounts of these animals' condition but also give readers a rather colourful impression of Wild's leisure activities and the labour of 'jockeying' as it is dutifully performed by his man. As I will argue here, Jony's removal in the Osborne copy bears the traces of a complex and compelling negotiation of larger political developments that had a bearing on both the state and local pleasures.

Among the many questions raised by the omission, this essay primarily focuses on two broad facets of Jony's characterization: his dialect and his profession. Because Jony's dialect provides somewhat inconclusive evidence about whether he was intended to represent an Englishman from the north or a Scot, we cannot positively identify his speech as a regional form of English or as the voice of what Shakespeare's Henry V referred to as England's 'giddy neighbor' (1.2.145). ${ }^{4}$ Nonetheless, I read the verbal markers of regional identity embedded in Jony's speech and his subsequent omission from the later work as an unambiguous act of erasure of cultural difference from the play. Along with the removal of other passages that resonate with the northern or Scottish sensibility that the horseman brings to the text, the Osborne copy, I will suggest, seems to indicate a concerted effort to remove any marker of geographical diversity and site specificity from the social world of the play.

I will consider, in this regard, the potential impact of the deteriorating relationship between England and Scotland in the late 1630s, exemplified in the rise and fall of James Arran, the Scottish marquis of Hamilton, at one time Charles I's master of the horse and, later, his chief advisor on Scottish affairs. I will then turn to cultural perceptions of horse-racing within the same period, noting how its history and politically fraught Caroline present are reflected in our sense of the horseman's role. All of these factors point to the complexity behind the deceptively simple solution of cutting Jony out. Finally, I will consider what may be dramaturgical reasons for Jony's excision from the Osborne version; these are bound to the play's characterization of the man that he serves, the suggestively-named character called Wild.

\section{Jony's National/Regional Identity}

Jony's omission changes little about the main plot of The Humorous Magistrate. Yet the stakes of his removal are higher than they may initially seem. 
Characters with dialects, such as Brome's Constance in The Northern Lasse (1632) and Norden in Ben Jonson's Bartholomew Fair (1614) speak to the value of regional identities as commodities on stage and in print, as Paula Blank has shown, whereas Shakespeare's Jamy in Henry $V(1623)$ and the entire plot of The Valiant Scot (1637) suggest their potential as a political liability. ${ }^{5}$ In the more familiar example, Shakespeare's 'Scots Captain' appears along with the Irish Captain MacMorris in the text of the 1623 folio but was apparently expunged from the 1600,1602, and 1619 quarto versions of the play. ${ }^{6}$ All of these plays encourage us to consider England's relationship to the north and to Scotland as possible explanations for Jony's absence from the Osborne text.

In their foundational critical accounts of the two manuscripts, neither Polito and Windle nor Kidnie expresses any doubt that the horseman missing from the Osborne manuscript is a Scot. Yet they and others began to challenge this initial assumption in two subsequent meetings centred on the two versions which were organized by Polito, Jacqueline Jenkins, and Susan Bennett. ${ }^{7}$ The Arbury playwright does not explicitly identify Jony as a Scot in the manuscript's dramatis personae; nor does any character invoke his national identity explicitly. The only overt reference to his ethnicity or origin in the play is his comment in act 1 advocating the practice of gripping a horse at the head; this riding technique, he contends, is one ' $\mathrm{w}$ ch the Southern men / ken not' (321-2), a claim that, along with his dialect and regionallyinflected words - the use of 'ken' for 'know', for instance — identifies him with the north. ${ }^{8}$ As Katie Wales notes, such designations are highly variable in meaning, depending on a speaker's own point of reference and the biases that necessarily accompany it. ${ }^{9}$ Jony's claim thus does not actually provide a definitive place of origin for him, since it could just as likely associate him with counties in the north of England as it could place his nativity north of the Scottish border.

Jony's association with the latter may have been signalled to early viewers or readers of this play by way of his explanation that his own knowledge of the grip came from being 'brought vp wi[th] Lory Spence' (322). Spence, a variant spelling of Spens, was a surname of Scottish origin, belonging to a clan of lowland Scots that settled in Fife, and shared by several notable Scots. In addition to the twelfth-century Scottish sailor made famous in the ballad of 'Sir Patrick Spens', Sir James Spence served James I as a diplomat in Sweden and several soldiers in his family went on to fight with distinction for Gustavus Adophus in the thirty years' war. ${ }^{10}$ We have yet to uncover records 
of a seventeenth-century Scottish horseman named Lory Spence, however, and contemporary manuals provide no more insight into the precise origin of his purportedly northern grip. Indeed, much like Jony, Gervase Markham, the author of multiple works on the art of horsemanship, occasionally uses 'northern' and 'southern' to designate different styles and practices in his works but never identifies a specific point of reference for either. ${ }^{11}$

Other words that pepper Jony's speeches, such as 'yan' and 'yen' (313) to indicate 'one', or the word 'swipper' (313) to mean 'swift', are indeed regional variants; like 'ken', they alone cannot be used to distinguish speakers from the northern counties from those from Scotland. ${ }^{12}$ Determining Jony's national identity presents a considerable challenge, then, as Scots and the northern dialect in England were more closely related to one another than either were to the English spoken in London and at court. As Blank notes,

Linguistically, Scots closely resembled the dialect of English spoken just on the other side of the national border; both were descended from the Northumbrian dialect of Anglo-Saxon. For many Scotsmen, in fact, Scots and English were virtually the same language ... In England, Scots was not considered [English] but rather the version spoken in the northern provinces ... Scots, with northern English, had retained more features of Anglo-Saxon than southern English had. On the contemporary linguistic map as drawn by Renaissance English writers, Scots was a province of English, an English dialect that had attained the status of a foreign national language. ${ }^{13}$

According to Blank, we can only truly differentiate between the two forms of non-standard English when playwrights indicate a character's national origin in more explicit terms. ${ }^{14}$ We are able to identify Shakespeare's Jamy as a Scot, for instance, because Captain Fluellen identifies him for us; in other cases, such as Nathaniel Woodes's Caconos in A Conflict of Conscience (1581), we find linguistic traits from both sides of the border and therefore cannot supply a single designation. In her discussion of this play, María Fuencisla García-Bermejo Giner refers to Caconos's 'Nothern/Scottish dialect' throughout. ${ }^{15}$ What this phrase lacks in discursive elegance is made up for by its prudence, and it may be as precise or specific as we can be with the horseman in the Arbury The Humorous Magistrate.

To be sure, some features are relatively unique to Scottish speech with respect to spelling or diction, or apparent pronunciation, even as the use of terms such as 'dialect' and 'language' to describe Scots remains controversial 
amongst linguists. ${ }^{16}$ Some of the features Blank suggests could be more distinctively Scottish than northern - the use of 'qu' for the prefix 'wh', and the personal pronoun combined with the present and future tenses of the verb 'to be', 'Ise' or 'Ist' - also feature prominently in the letters of Scottish women from the period, texts mined by linguists as evidence for the phonetics of authentic speech, since women writing these letters typically lacked the formal education that led to more standardized (and more anglicized) spellings in the written works of Scottish men. ${ }^{17}$

Exaggerated versions of Scots dialect circulated on both sides of the border in broadside ballads, works that, as Gerald Porter argues, underscore English writers' clear 'preoccupation with difference'. ${ }^{18}$ In these texts, he claims, 'a clumsy parody of Scottish speech is achieved by the liberal use of "gang" and "muckle", a set of cues that he describes by taking recourse to the playhouse, deeming such speech not Scottish, but merely 'stage-Scots'. ${ }^{19}$ According to Porter, stage-Scots is used 'in almost every case as a distorted way of speaking English rather than a mother tongue'. Although actual Scots dialects varied according to region, some semblance of 'Scottishness' could be constructed credibly enough for English audiences from a 'handful of Scots words, such as gang, muckle, guid and lass. ${ }^{20}$

In the Arbury version of The Humorous Magistrate, the playwright's attempt at writing a dialect entails some of the forms that appear in the ballads and women's letters, including 'gud' for 'good' (323) and the exclusive use of 'I's' $(341,1279,2830)$ and 'Ist' $(320,326,332,334)$ in place of first-person forms of the verb 'to be' when Jony indicates his opinions and intentions. ${ }^{21}$ In one instance in the Arbury manuscript, the playwright or the scribe has scratched out 'I am', replacing it with 'I's'. The playwright also uses 'gang' $(299,310)$ for going or gone, 'weel' for well, and 'mere' for more, 'luke' (1269) for look, and 'mickle' to indicate great or much (310). Katie Wales describes many of these examples as 'stereotypical "far Northern"/Scots forms' but also contends that none provides conclusive evidence of one dialect over the other. ${ }^{22}$ Although Jony does not use the possibly more telling pronunciation that would be implied by 'qu' spelling for words beginning with 'wh', some of the playwright's spellings (such as 'Spaile' for spoil [309] and 'Warth' for worth [310]) seem to aim at replicating the kinds of Scottish pronunciations that phonetic spellings in letters suggest; his reference to a 'lerd' (1271) likewise invokes the Scottish 'laird' rather than the English 'lord'.

In addition to replicating some of the same markers that we see in ballads and Scottish epistles as well as plays and other literary works, the 
Arbury playwright's attempted dialect shares cues for Scottishness deployed by Shakespeare, who made infrequent but significant use of dialect in his depiction of the three captains from the Celtic fringe in Henry $V^{23}$ Along with MacMorris's repeated interjection, 'What ish my nation?' (3.3.61-3) and Fluellen's commentary on 'Alexander the Pig' (4.7.12), Captain Jamy's earnest speech on his military commitments provides a distinctly non-English expression of national identity - even as the nation he represents has been easily appropriated for England in the context of war against France. In response to the bickering Welsh and Irish captains, Jamy tells his comrades,

by the mess, ere these eyes of mine take themselves to slumber, ay'll de gud service, or I'll lig i'th'grund for that. Ay owe Got a death, and I'll pay't as valorously as I may, that sall I suirely do, that is the brief and the long. Marry, I wad full fain heard some question 'tween you twae. (3.3.54-9)

Some of the unique indicators of Jamy's dialect include his use of 'Got' for 'God', the contracted phrase 'lig I'th'grund' for 'lie in the ground', 'Ay' for 'I', 'sall' for 'shall', and 'twae' for 'two'. Jamy shares with Jony the distinction of being excluded from some versions of the same play, and they also share a few dialect cues; among them, we find 'Wad' for 'would' (296) and 'gud' for 'good' (323). Additionally, though the oath is not exclusive to Scots dialect, both Shakespeare and the Arbury playwright use forms of mild oaths to the Virgin 'Mary', perhaps an allusion to an earlier Catholic Scotland under Mary, Queen of Scots. Jamy utters this oath twice; Jony three times (303, 308, and 323). The same oath appears six times in J.W.'s The Valiant Scot (1637) and eight in John Tatham's commonwealth play The Scots Figgaries (1652). ${ }^{24}$

Both J.W. and Tatham use 'twa' and 'twae' to indicate 'two' in the same manner as Captain Jamy, though the two later playwrights also use markers of dialect that do not appear in either Henry $V$ or in Jony's lines. The Valiant Scot and The Scots Figgaries contain multiple instances in which the playwrights use 'oo' in place of 'ou' sounds, substitute 'v' sounds with the letter ' $\mathrm{f}$ ' (as in 'gif' or 'guiff' for 'give') and use 'eo' instead of a double 'o' in words such as 'leok' for 'look'. The Scottish beggars in Tatham's work use the same personal pronoun form as Jony uses (predominantly 'Is' or related forms) as well as the verb 'gang' for 'go'. These features are exemplified in Tatham's play in one Scot's promise to an Englishman, 'Ise gang aboot it stret, Ise gang aboot it sir' (2.175). Jony and the Scots in the two seventeenth-century plays 
also use 'yar' $(296,315,1276)$ to indicate the second person possessive 'your'; the Arbury The Humorous Magistrate use of 'sike' for 'such' is also consistent with Scottish characters in both The Valiant Scot and The Scots Figgaries.

Although Jony's speeches feature several words and word forms in common with works containing characters explicitly named as Scotsmen, they also share features with characters in other plays identified as simply from 'the north'. Both Jonson's Nordern in Bartholomew Fair and Jony use 'ne' for 'no' (4.4.3 and 308, respectively) and Jony's 'mere' (1270) is comparable to Nordern's 'mare' (4.4.3). ${ }^{25}$ Nordern's replacement of the fricative ' $f$ ' with ' $v$ ' in claiming to be too 'vull' (4.4.12) of 'eale' (ale) (4.4.3) has no counterpart in the Arbury play but as both Katie Wales and Paula Blank note, Jonson's deployment of dialects was far from systematic. ${ }^{26} \mathrm{~A}$ better example of northern dialect for comparison is The Northern Lass by Richard Brome, whose titular heroine Constance features more prominently than does Jonson's Nordern. Brome and his characters speak of her more than she herself is given opportunity to speak but in the instances in which the playwright does give her lines, 'she is Northern', as Mistress Fitchow notes, 'and speaks so' (2.1). ${ }^{27}$ Constance's dialect is marked in the play by Brome's phonetic spellings'gude' for 'good', 'wee'll' for 'well' (3.2), and 'geane' for 'gone' (2.3) - and his use of 'mickle' to mean 'much' (twice in 2.4).

Along with these examples, Brome's spelling of 'luke' for 'look' matches the Arbury's use for Jony's lines (1269) and words that Constance does not have in common with the horseman sometimes correspond with or approximate those used by Scottish characters in other works. Her use of 'mun' (3.2) for 'must', for example, matches the character Peggie Graham's deployment of the same word in several instances in The Valiant Scot. Though Constance uses the verbal construction 'I is' as a form of 'I am' in a few brief instances, she uses other tenses of 'to be' such as 'I will' and 'I would' (5.1) more often; this compound of personal pronoun and verb (rather than combining them in a single word) is one the few obvious differences between her speech and that of Scottish characters in other works and between her speech and Jony's in the Arbury The Humorous Magistrate.

We find a more stark contrast in the number of times dialect words and phonetic spellings feature in each character's speech. Constance uses words that appear to be dialect cues by a ratio of roughly one to every six non-variant words; dialect cues appear in Jony's speeches at a ratio of one unique form to every four words that conform with the spelling standards apparent elsewhere in that version of the play. Thus the Arbury playwright's use of non-standard 
variants and unique or phonetic spellings for Jony's speech is more pervasive than is Brome's usage for Constance. It does not, however, rise to the percentage of dialect words that we see in J.W.'s play; in The Valiant Scot, Peggie Graham's speeches contain standard or common spellings for words only about half of the time, roughly the same ratio of standard forms to unique forms that we see in the speeches of Shakespeare's Jamy. ${ }^{28}$

We might, by these figures, surmise that higher ratios of dialect cues to standard spellings mark a speaker's status as foreign precisely by degree, allowing playwrights to impress upon viewers a sense of the distance between a character's current location and his origins by the sheer number of words that audibly estrange the speaker from all of the other inhabitants of a given fictional world or geographical location. This assumption has some support in the fact that the greatest preponderance of dialect words correlates with Scottish characters rather than those from the north. Still, spelling was not fully standardized in the period and what may look like unique or deliberate variants in the published works of professional dramatists could just as likely reflect the work of scribes, stationers, or anyone else involved in the enterprise of transmission as they might register authorial intent. Even if we suppose that a more direct relationship existed between the Arbury manuscript and household performance than between printed works and their staging at the playhouse, neither manuscript nor printed text offers sufficient means for gauging registers of the spoken voice in performance.

Even if we concede, moreover, that numerical counts allow for an objective account of a concrete linguistic phenomenon, no exact equation could allow us to correlate a specific number of dialect words and unique spellings with 'Scottishness'. In his study of broadside ballads, Porter argues that 'there is an inverse relation between the number of Scots words and the degree of hostility and stereotyping. The higher the proportion of dialect, the more inward and complex the understanding of cultural difference.' ${ }^{29}$ Yet this same claim does not seem to hold true for dramatic works. The play that demonstrates the most pervasive use of non-standard forms, Tatham's Scots Figgaries, is indeed the one that is most overtly invested in stereotyping, criminalizing, and therein simplifying, its titular Scots. ${ }^{30}$

Even when characters are explicitly identified as Scottish, it is not always apparent whether the use of dialect is intended to mock or merely separate assuming, that is, that a writer could do the latter without necessarily doing the former by default. The Valiant Scot, for instance, almost fetishizes dialect in using its sole female character to link the speech of Scotland to English 
atrocities and its past victimization; Peggie rebuffs an Englishman's insult by saying,

Hange yare flee-flapps, na Scirrush woeman is asheamed a that luke, that the master painter abuise guifes her,

words that make an obviously sympathetic character sound laughable to the modern ear. At the same time, J.W. also complicates this use of dialect in his depiction of William Wallace, whose speech is devoid of any dialect cues throughout most of the play. In a significant scene in which Wallace dons a disguise in order to elude his pursuers, however, he also takes up a new, mocking speech, telling the Englishman he intends to trick, 'Ize a Scotch man sir', and claims to condemn 'wha that fawse traytor Wallace has misusand in sike wise' (2.4.84-5). Here, Wallace exploits English expectations, mocking their idea of what it sounds like to be a Scot while also convincing the men that he is neither the rebel they are sent to apprehend nor a threat to their king's agenda.

Because of the marginal and largely comic nature of Jony's role in The Humorous Magistrate's plot, Jony's inflected speech seems more ambivalent than the dialects of Scottish characters in The Scots Figgaries and the earlier Valiant Scot. His place in the play bears greater resemblance to Shakespeare's Jamy, who appears briefly to speak and marks himself as a Scot without simultaneously marking himself as a fool. Still, Jamy's Scottishness has a clearer purpose in the context of Shakespeare's history play than does Jony's brand of difference in the Arbury manuscript. Whether the former's inclusion or exclusion in quartos of Henry $V$ indicate deference to or criticism of James I, Shakespeare needs a Scottish Jamy to show Henry's ability to marshal the loyalties of 'the weasel scot' away from his 'auld alliance' with France to rally behind England. ${ }^{31}$ Why might the Arbury playwright need a Scottish horseman, or for that matter a horseman from the north?

\section{A Scottish Horseman at the English Court}

One way we might begin to answer such a question would be to consider Jony's presence and absence in the context of the career of Charles I's favorite, James Arran, marquis of Hamilton, a Scot who had replaced the duke of Buckingham as the Master of Horse in 1628. Hamilton was the named dedicatee of the printed text of The Valiant Scot, and perhaps more significantly, 
of Thomas de La Grey's The Compleat Horseman (1639) as well. In addressing the marquis in that work, de La Grey praised his particular service in horsemanship, exclaiming,

Let it therefore bee recorded, (my Noble Lord) that whilst you were Master of the Horse to his Maiestie, an exact observation was established throughout this whole Kingdome, for the due breeding of serviceable Horses, to the furtherance of which most Noble designe ... shall bless my Pen that it ever waded in such a subject. $^{32}$

There is little reason to believe that these claims are anything more than the inflated praise typically allotted to a text's dedicatee. After all, the letter preceding the printed text of J.W.'s Valiant Scot invokes Hamilton's military prowess and love for Scotland when, in fact, few subjects in England and Scotland believed he had much of either. ${ }^{33}$ Whether Hamilton was, as de La Grey professed, a crown officer whose tenure markedly improved the status of both horses and horsemanship in Britain, the fact that a Scot held the office from the late 1620s may indeed have some bearing on our sense of Jony's role in the manuscript of The Humorous Magistrate in the Arbury miscellany. While the marquis's career may not provide a magic key for unlocking the secrets of Jony's Scottishness, it could shed some light on the character's absence in the Osborne version if he was, in fact, intended to be Scottish.

The years between the two copies correspond with Hamilton's attainment of additional titles and positions, including the office of royal commissioner, in which capacity he would encourage King Charles to wage war on his own Scottish subjects for protesting the king's attempt to enforce an English prayerbook in the Scottish church. In fact, the same year de La Grey praised his career as Master of the Horse, Hamilton led troops across the northern border against his own native country in the campaigns historians refer to collectively as the bishops' wars, an enterprise that had (for England and for Hamilton) disastrous results. ${ }^{34}$ If the Arbury copy was indeed composed in the late 1630s and the Osborne copy after 1640, the removal of a Scotsman in the later copy may be understood as a judicious amputation.

Certainly, while the north occasionally looms in drama and historical record as a site of cultural difference and local rebellion, Scotland was frequently perceived as a more dangerous and sometimes imperial threat. In spite of the clear similarities between northern and Scottish speech, dialect cues for characters explicitly named as Scots at specific moments in time necessarily 
would have performed cultural and ideological work distinct from those cues identified only as northern. The basic fact the Scots were designated enemies after 1638 - and more pointedly, that Scottish forces handily rebuffed English troops in campaigns in 1639 and 1640 - would have rendered any dramatic representation of a Scotsman problematic, if not outright dangerous, after 1640. According to one sensational account, the act of staging an impromptu performance of The Valiant Scot in 1641 was enough to land its players in jail. ${ }^{35}$ If the copyist or playwright who reworked The Humorous Magistrate in its latest extant form was not troubled by the perils of public performance, he nonetheless must have understood that the social currency and political signification of the dramatic Scotsman had shifted since the play's initial composition - and continued to be unstable. In fact, after the bishops' wars, the Scots' allegiance was a commodity coveted by Charles and members of parliament alike in the lead-up to civil war and they would forge and break alliances with both parties as conflicts at the borders burgeoned into the wars of three kingdoms. In the years just before and after this time, a figure like Jony may have invited more discomfort from household visitors than applause.

\section{Other Omissions}

Yet Jony's removal is not the only difference between the Arbury and Osborne manuscripts that raises questions about the political implications of figures from Scotland or the north. The Arbury The Humorous Magistrate contains a woman named Tib in a scene in which two of the play's lovers, Kit Spruse and the titular magistrate's daughter Constance, escape to the country and find themselves in the company of a group of singing and dancing shepherds. ${ }^{36}$ The name 'Tib' is a Scottish diminutive and, like Jony, her speeches contain markers for Scottish or northern dialect such as 'de' for 'do' (2319) and 'ha' for 'have' (2321). The playwright suggests Tib's possible Scottish roots, moreover, in the drink she presents to the Shepherd King, an ale she describes as the work of a 'a clanly woman' (2318). ${ }^{37}$

Although Tib survives into the Osborne version, her role therein is considerably reduced; whereas in the Arbury the Shepherd King chooses her specifically as the 'wench to my selfe' (2304), an act he seals with a kiss and (apparently) a swig of the ale, in the Osborne manuscript, she is simply one of several women 'of the downes' (2356) that he welcomes into the fold. Although the king addresses her by name, Tib does not speak; and so with the 
removal of her dialogue, the playwright or the scribe removed the markers of dialect from her speech as well as the 'clanly' origin of her ale. Such revisions seem minor in isolation from Jony's removal from the play; yet, taken along with the horseman's absence, the reduction in Tib's part and the apparent 'norming' of the country-folk's speeches appear to be part of a systematic effort to excise regional markers of cultural difference from the play.

To be sure, the scene in which Constance is entertained by the Shepherd King, akin to the plots of pastoral escape we see in Shakespeare's The Winters Tale (c 1610) and part-time roguery in Brome's A Jovial Crew (1641), does retain an oblique reference to the north by virtue of the king's reference to 'Mountain Poetry', a phrase that he uses in both texts. As Blank's work on dialect and its relationship to literary form demonstrates, sixteenth-century poets typically associated dialects and archaisms with pastoral poetry and the north, giving rustic characters regionally-inflected cues to link them with older and more 'pure' forms of English. Spenser, whose Colin Clout occasionally speaks with such cues, also made frequent use of a motif in which mountains or high hills denote the north, endowing it with the fertile ground that gave rise to the earliest blooms of English poetry.

In the Arbury version, the Shepherd King requests that the musicians provide a tune for 'pure mountaine Poetry' that he claims is of ' $\mathrm{o}$ ' own making' (2296). In the Osborne version, he welcomes Tib and other 'country wenches' 'to th'hill' and informs them that they will 'heare a sonet of mountain poetrye' (1456-7). While the Osborne reference to the hill gestures upwardly to the mythic origin story perpetuated by Spenser and his contemporaries, the Shepherd King in this version does not identify the 'mountaine poetry' as pure or his own. That this scene remains in the Osborne copy of The Humorous Magistrate suggests the playwright's desire to make use of literary tropes and styles that evoke figurative geographies without making their literal locations plottable on a map that had potentially fraught political resonance.

The Arbury's more concrete representations of regional identity in the pastoral scene are particularly interesting in light of the Osborne version's other omissions of directional references or allusions to specific locales. Without Jony, The Humorous Magistrate is almost entirely lacking such references. If the play is 'purpose-built country drama', that purpose does not seem to include the promotion of the estate or shire in which it was produced; the text defies any sense it has a geographical provenance at all. ${ }^{38}$ The fact that the Osborne text takes this turn seems odd given that around the same time, poems such as 'To Penshurst' were circulating in manuscript and in print in 
public celebration of the estates of the wealthy. Accordingly, it seems all the more compelling that the play's only references to precise locations appear in the Arbury exchanges between Jony and Wild. As I will discuss in the section that follows, we cannot explain the omission of these locations in the Osborne copy solely in light of the horseman's associations with either Scotland or the north. His speeches in the Arbury manuscript associate him with places in the middle and south of England as much as his dialect implies his origins in regions to their north and so we must look to Jony's profession and the locations associated with it such as Hyde Park and other sites in which horse-racing took place.

\section{Jony's Profession}

Certainly, the references to places affiliated with racing make sense in light of Jony's apparent profession. Though the Arbury dramatis personae lists him simply as Wild's 'man', the labour he performs (and the labour the play suggests he performs outside of its staged action) is related to the keeping, riding, and racing of horses, including putting wagers on the latter on behalf of his master. If his removal from the Osborne manuscript tempts us to see his character as utterly expendable in the play's plot, his place in the Arbury manuscript allows us to see the figure of the horseman as part of the play's commentary on social rank, country life, and gender. Indeed, Jony provides a thematic complement to the play's depiction of the antics and subsequent punishment of a female character named Jennet, a woman whose equine name foreshadows her judicial sentence of 'carting' by Thrifty: to pull a cart (rather than be pulled in one) for allowing her younger charge, Constance, to escape with her suitor, Spruse. Although the Osborne manuscript retains the female character ('Jenet' in this version), its omission of Jony means that her punishment no longer resonates with a larger strain of figurative language and the play itself loses a degree of symmetry in the imagery that had, in the Arbury, emphasized significant connections between people in service positions in the play's multiple plots.

By his own description, Jony is a 'jockey', a word that could have signalled his identity as both horseman and Scot. In ballads and broadsides printed in England and Scotland, 'Jockie' or 'Jocky' is a stock name for labouring-class Scots as well as Scottish beggars and scoundrels; indeed, it is the name of the most prominent (and apparently for Tatham, the most despicable Scot) in The Scots Figgaries. ${ }^{39}$ In stark contrast to the derision aimed at Scots in 
the Commonwealth play by Tatham, the Caroline The Humorous Magistrate does not vilify Jony's character for being a 'jockey' or make him the butt of xenophobic jokes; rather, the Arbury manuscript allows Jony to make the jokes himself, literally and figuratively disrupting domestic space and social decorum, if only very briefly.

Act 1 finds him discussing the readiness and merits of various horses, and the basic content and structure of his speeches resemble those of Shakespeare's Lord and the Hunters in the Induction of The Taming of the Shrew as they engage in a spirited discussion of whether Brach Merriman, Clowder, Silver, Belman, or Echo is the best hound. Animal names, and a lively assessment of the relative merits of the creatures to which they belong, likewise form a significant portion of Jony's lines; his first line is a report that the 'gray neg is sadled' (292) and those that follow in response to Wild's question about the status of a single horse named Fenek entail a run-down of an entire stable's worth of beasts, among them Robin, Hawden, Hering, and Hawksworth (108-321).

In The Taming of the Shrew, the conversation with multiple dog names is a brief but nonetheless suggestive episode in the play's development of themes and characters, foregrounding, in particular, the recreational habits of the country gentleman as well as the tenor of male competition and its typical manifestation in betting over both beasts and women. Shakespeare's comedy conflates these two categories of subordinates in its title and in scenes in which obedient spouses are configured in terms of hunting and hawking. Like the tavern talk in the Induction of Taming of the Shrew, Jony's planning with Wild provides a colourful picture of equestrian sport and the attendant gaming and competition that the 'aeyring' (293) of horses enables amongst men. ${ }^{40}$ This picture has even greater resonance in a play more contemporary with the Arbury manuscript, as it enables a comic paralleling of horsematches and love matches in the manner that James Shirley made popular in his contemporary play, Hyde Park (1637).

As Elspeth Graham notes of Hyde Park, the play invokes racing and marriage as 'overlapping discourses', using 'horse-racing as a thematic analogue to the romantic concerns of its characters. ${ }^{41}$ Likewise, in the Arbury play, Jony's comments about horses frame and sometimes interrupt his master Wild's attempts to woo Miss Sophia Mumble; they also inflect, though less directly, the attempted wooing and secret congress of the more prominent pair, Spruse and Constance. Some of the names of horses Jony lists in his assessment of Wild's prospects at the races suggest that the Arbury playwright was familiar 
with racing and with Shirley's play. Among them are Constable, Peggabrig, and Kildeere, all of which feature in the ditty sung by Shirley's comic wooer, Venture, who exhorts his comrades, as Jony does Wild, to put in money to 'Make the match' (Hyde Park G, The Humorous Magistrate 327):

Young Constable and kill deeres famous,

The Cat the Mouse and Noddy Gray,

With nimble Pegabrig you cannot shame us,

With Spaniard nor with Spinola.

Whether these names and the ditty itself were Shirley's invention or known as conventional in the cultural arena of racing, the Arbury The Humorous Magistrate invokes horse-racing in a manner much like Hyde Park - that is, as a potentially lucrative form of sport and entertainment.

Placing the Arbury play in this particular dramatic and recreational context enables a recalibration of the country house play's geographical landscape or scope, for it connects the private estates of Thrifty and Mumble to more heavily populated areas and public sites in the same way the Arbury's references to Hamlet gesture at the playhouses in England's urban centre. ${ }^{43}$ In addition to describing the horses and potential riders, Jony references a match at Banstead, a Parish well-known for sporting events and especially horsematches by the mid-1620s, as well as three other locations for racing that are proximate to where the playwright lived and wrote; Jony's knowledge of current races extends from Coventry (336) in the west Midlands, to Lincoln (328) in Lincolnshire County and Kiplingcotes (328) in Yorkshire.

Although the races are more marginal to the love plots in the manuscript play than they are in Shirley's better-known work, they nonetheless function in the same manner as the race that is central to the resolution of Hyde Park. In underscoring that such events provided an opportunity for labouring classes to interact with members of a class wealthy enough to own horses, both plays record a sense of broad cultural interest in what was, in the 1630s, a relatively new, royally-patronized public activity. While regular races had taken place in England since the reign of Henry VIII, historians credit James I for popularizing the sport more widely through his attendance at and patronage of several matches. Starting with Heath and Newmarket in 1617 and 1619, respectively, and at least two other courses nearby in following years, James reinforced the notion that horse-races were annual events that warranted regular attendance. ${ }^{44}$ Charles I followed his father's legacy by 
bestowing on the earl of Holland the title of keeper of Hyde Park and, more importantly, by encouraging him to open it up to the public. ${ }^{45}$

Shirley dedicated the printed edition of Hyde Park to the earl in 1637, an act typically understood (and implied by Shirley himself) as a celebration of the occasion and the democratization of space that it so remarkably entailed. ${ }^{46}$ But if Hyde Park underscores the potential for horse-racing to level or muddle class distinctions, the play also prefigures the social conflicts resulting from the mingling of social classes that the park enabled. According to Martin Butler, although the park's opening was transformative in its particular cultural moment of the1630s, its typical operations not only pitted but also reaffirmed traditional notions of land and blood-based nobility against a newer-money gambling class. As Elspeth Graham argues, 'If, at that moment, the values of an emergent class can be celebrated in a play such as Hyde Park, the history and nature of the space that gives reference to Shirley's play also contains within it signs of the tensions that will come to surround those values. 47

Such tensions also are manifest in the Arbury The Humorous Magistrate's discussions of horse-racing, surfacing in the two brief dramatic moments that contain Jony's most substantive lines. In his second appearance in the play, he upbraids Spruse for keeping Wild occupied too long in helping him woo Constance, setting up one fair match against another:

I wonder you's take away my master you's make him lewse the fairest match that euer had man the deels ha me $S^{r}$, tis vara weel if a yong neg get his charges the first yeare of his trening.

Although Jony's speech is ostensibly protective of Wild's financial interests, the master rebukes his man for being 'so vnmanerly to press in where gentlewomen are!' (1296-7). Jony replies with the following quip:

Why pre $\mathrm{s}^{\mathrm{r}}$ are not all horsemen gentlemen[?] I haue heard of a Lady has done penance for lying $\mathrm{w}^{\text {th }} \mathrm{a}[\mathrm{g}]^{\mathrm{r}} \operatorname{coach}^{\mathrm{T}}=$ man, $\&$ then tis no hurt for [hum] $\wedge^{\text {'gentlewomen }}{ }^{\top}$ ta luke vpon a horse man. I [am] 's' sure $S^{r}$ horsemen oft get mere then their mast $\mathrm{t}^{\mathrm{rs}} \&$ though seldome a Iockie turne Lerd, yet a Lerd will often times turn a Iockie.

$(1267-72)^{48}$

This joke turns on the implied reversal of class hierarchies and privilege and in uttering it, Jony claims a professional, if not blood, nobility and sexual 
prowess for those who share his brand of labour. The play echoes this amusing juxtaposition of lords and jockies in a later instance, when Crisp tells his master, Kit Spruse, of his mother's impending union with Justice Thrifty by describing it as a match made in a world-turned-upside down. Using a conceit that the playwright initially ascribed to Wild (lines 1801 and following) but crossed out and reassigned at a later point, Crisp informs Spruse that:

the newes is strange

both in the town \& countrye, for I heare, that soldiers

are led by gownemen, $\&$ pikes $\&$ musketiers make a re= treat from bickbats, fleetstreet is become mile end $\&$ more fields a bleching place, barbers haue their mustachioes turnd vp by $\mathrm{y}^{\mathrm{eir}} \mathrm{m}^{\mathrm{rs}}$, \& Iockies their stirrups held by $\mathrm{y}^{\mathrm{eir}}$ Lords, Iustice Thrifty^ $\wedge^{\top}$ has $^{\top}$ maried $\mathrm{yo}^{\mathrm{r}}$ moth $^{\mathrm{r}} S^{\mathrm{r}}$

In the Arbury's last image preceding the reference to Thrifty and Mumble's marriage, Spruse deploys the expression 'to hold the stirrup', a verbal phrase whose literal sense the $O E D$ records as 'helping a person to mount, esp. as a manifestation of homage or reverence'; figuratively, it carries the sense 'to be subservient'. ${ }^{49}$ Thus in Crisp's joke that 'Iockies their stirrups held by $y^{\text {eir }}$ Lords', the figure of the horseman once again emphasizes a subversion or disruption of existing class structure in which a gentlemen's status is encroached upon or supplanted by his social inferior. That these lines were originally placed in the mouth of the one character who seems to have regular contact with a jockey in the play is probably significant, though it is difficult to know what to make of this specific revision. Nothing explicit in the play suggests that Wild is in danger of losing ground to his man, though in the version of the play without the jockey, he appears to be on more stable economic footing.

The Arbury playwright was not alone in exploiting this jockey conceit, for it appears in some fashion in several other texts. Brome's Antipodes (1638), for instance, includes a similar joke that suggests an amusing but also potentially uneasy brand of competition between men of status and their horsemen in Letoy's declaration,

Let my fine Lords

Talke o' their Horse-tricks, and their Jockies, that Can out-talke them..$^{50}$ 
It also appears in another form in a work once attributed to Thomas Dekker, and now to Thomas Middleton, The Owles Almanacke (1618), which predicts that 'a Iockie that rodde on his Courser ... shall suddenly leape into his tuftaffity' and become a 'a Gentleman now' as one of the 'many strange accidents which shall happen to this kingdome of Great Britaine this yeere.51 In invoking the figure of the jockey, these works exploit the puns available in two competing senses of the word. References to 'jockies' in each instance plays on the sense of 'one who manages or has to do with horses' as well as another common sense conveying a beggar or vagabond. In fact, the subservience entailed in Jony's profession is also encoded in his name; the $O E D$ records Jony as the diminutive or 'pet-form' of Jock or Jacky, and Jockey as the 'diminutive or familiar by-form of the name Jock or John ... usually with the sense "little Jock, Jacky, Johnny" ... hence, applicable (contemptuously) to any man of the common people. 52

That the socially aspirant, gaming jockey might not have been appreciated by some members of the nobility is indicated in Baron Dudley North's A Forest of Varieties (1645), a print miscellany that contains a poem in which the tale of 'Iockey and his Horse ... by their Master sent / To honour him in hunting, run, and race' nearly ends in the master's disgrace. 'The iockey became engaged to a match, / Which cost him dear', North explains, and required a gentle intervention:

The Master now came in, to this disorder, And finding Jockeyes want of strength and skill,

By his all-taming art, brought all in order,

And fashioned horse and man unto his will.

Thus right, and each to other fitted well,

They are to run, and cannot misse the bell. ${ }^{53}$

If North's poem advertises the gentleman's natural ability to master both his beast and his servant's unbridled spirits, it also speaks to his anxiety about the ruin that a bad horse-match could bring to the landed class. ${ }^{54}$ Robert Burton clearly concurred, noting in his Anatomy of Melancholy (1621) that, among several 'disports of greater men', 'horse-races ... are and good in themselues, though many Gentlemen by that meanes, gallop quite out of their fortunes. 55

In 1621, King James saw fit to regulate betting at races in Scotland for this reason, issuing a proclamation that limited any one person 'to gaine at Wagers upon Horse Races any summe attour the said summe of an Hundred 
Merks'. ${ }^{56}$ Perhaps surprisingly, the king attempted no such legislation in England and over the course of the century, racing earned an association with knavery and gradually institutionalized forms of dishonesty. According to John Burnett, 'though many respectable men were connected to it, it was not itself quite respectable' and by the eighteenth century, he writes, 'the world of horse-racing was well developed in England, with numbers of inns with racing competitions and knowing ostlers, aristocratic owners and sporting gentlemen, horse nobblers and other disreputable individuals seeking an advantage over a half crown whereever they might find it. ${ }^{57}$

To be sure, the association of English horse-matches with more troubling forms of debauchery - prostitution, for instance - would not dominate cultural perceptions of the so-called 'sport of kings' for nearly a century after James had first graced spectators with his presence at Newmarket Heath. Yet the anonymous ballad, Nevvs from Hide-Parke, printed in 1640 or shortly thereafter, suggests that anxieties about the economies and modes of exchange that racing made possible and precarious were starting to surface much earlier. In a manner similar to A Forest of Varieties and Burton's Anatomy of Melancholy, the ballad gives voice to concerns that the noblemen who attended the races could meet their ruin there. Nevvs from Hide-Parke is a humorous allegory in which a young 'north-country gentleman' goes to see horses, but finds instead a 'lady of pleasure' and decides to escort her home. She turns out to be the devil, an identity the young man learns only after he has persuaded her to 'yield' to him in bed. ${ }^{58}$ Like North's poem and Burton's punning commentary, the ballad shows the attraction of Hyde Park and its ilk as a 'Lady Faire' as well as the potentially long-lasting consequences of interacting with the people there.

\section{Wild (and) Horses}

Contemporary responses to races and their audiences invite us to consider the removal of Jony the horseman from the more polite company of men in the Osborne version in terms of his master's romantic dealings. Indeed, Jony is a reflection not just of the wagering associated with racing, but also of his master's worthiness as a suitor for Sophia. Jony enables the characterization of a Mr Wild who is most befitting of his name. Such a character, however, is less apparently fit for a solvent marriage. Just as Jony's omission encourages more politicized assessments of the revisions made to Tib's character and role in the play, his presence and absence likewise can inform how we 
understand other omitted references to horses and gambling, some of which are not explicitly linked to Jony but have some notional or thematic relation to what he represents. For instance, other references to horses are omitted from the Osborne manuscript, including Parchment's claim in the Arbury to have 'light[ed] of the gray gelding' (942) in order to send a message to his wife. After his exit, Jennet's comments to Spruse, lamenting 'the times' and 'fine world' in which 'a master of a company will reueale the secret of a trade' also invoke horses in a confusing (and likely figurative) description of Thrifty as a man ' $y^{t}$ rode oth' black horse pay o ${ }^{r}$ fees $\&$ trade $\wedge^{\text {'afresh }}$ ", (Arbury 957). The Osborne's revisions clarify the sense of Jennet's remarks by simplifying the speech preceding this reference; she calls Thrifty instead 'old heauie vnwieldye gentleman' (Osborne 660) and sulks at his hypocrisy for 'tempt[ing her] to sin' and then 'punish[ing her] for doing it' (Osborne 662-3). Whether the description of Thrifty as a rider has been removed here to improve clarity or for some other reason is not clear.

Other revisions, omissions, or removals seem more likely to be aimed at making Wild appear at least marginally less 'wild'. The elimination of the discussion between Wild and Crisp in Arbury's act 3, scene 1, for instance, entails the removal of Crisp's assessment of Wild as 'great a gamster as any' (1176) along with Wild's boasting confirmation of that assessment as fact. Also missing from the Osborne manuscript are his comments as he takes leave of Constance and Spruse after Jony makes his jockey quip in act 3; Wild tells his friends 'I onely take the liberty to article for / a horsematch' (1284) and promises a quick return. After an apparently lengthy delay, Wild returns and, in lieu of genuine apology, boasts to Constance that he has spent his time in a

$$
\text { good iest }
$$

To see how fellowes liue about the towne

To foole away their mony.

As the lines that follow indicate, the 'good iest' that has kept him from returning to Constance to assist in her escape with Spruse has involved tricking a 'yong fellow' (1343) into parting with his money and possibly providing a horse to enter in an upcoming match at Hyde Park. Wild then invites Constance to attend the match, claiming 'Twill be a good recrea=/ tion in an Euening for you to giue vs the looking / on' (1372-4). Constance's response, had the playwright allowed her to utter it, might have reinforced the notion that Wild's ventures make him not merely a gambler but also a thief. She is 
prevented from responding, however, by Spruse, who interrupts with his own boast about giving Constance a ride in his new coach.

Though we have no explicit condemnation of Wild's recreational pleasures within the Arbury text, the Osborne's omission of these scenes, along with the enabling service of his man Jony, do suggest that the playwright determined that Wild had to be toned down if not entirely tamed. It is worth noting that two references to horses do appear in the Osborne version of The Humorous Magistrate in addition to the implied reference in the carting of Jennet but they present a far more muted version of the thematic thread that, in the Arbury version, binds together disparate comments on gender that reflect directly on Jenet's punishment. In both versions of the play, she is deemed as 'the old iade' (Arbury 995, Osborne 697), a designation that echoes Jony's earlier use of the same word in the Arbury in reference to the horse named Hering (336) and foreshadows her sentence to pull a cart for not keeping track of Constance.

We also find a similar instance of foreshadowing in the Osborne copy in a short passage that was added to the text. Perhaps intended to convey in shorthand form the many conceits in the Arbury involving horses and betting, it places a racing metaphor in the mouth of Justice Thrifty, who, at the conclusion of a lengthy diatribe cataloguing rogues, manages also to work in a warning to Jennet's husband and a constable about the criminality of aspirant, unfaithful women: 'for $\mathrm{yo}^{\mathrm{r}}$ high comers, that will beat a coruet as loftilye as a courser of Naples, I mean $y^{\mathrm{r}}{ }^{\mathrm{w}}$ women peccants, they shall be all fettered to keep 'hem from stradling, euery woman that can but wag a leg' (261-5). In envisioning 'women peccants' as 'high comers' that execute jumps as easily as Italian race horses, Thrifty implies that female rogues might easily escape from imprisonment; but the notion that 'they shall be fettered' to keep them from 'straddling' suggests not only ensuring their confinement, but also preventing their sexual activity. In this particular comment, then, the Osborne play activates several of the erotic and gendered valences enabled by metaphors related to horses and racing but does so in a manner that does not implicate Wild, a character who needs to provide a reasonable match for Sophia Mumble and thus to be distanced from any roguish dealings. In fact, the Osborne text projects dissolute and criminal behavior almost solely onto Thrifty's sometime mistress, even as her supposed crime is something that Spruse and Wild purposely engineer and even as the play makes light of the fact that Thrifty himself is corrupt. Male wooers in the later manuscript remain untainted by the association 
with disreputable activities and financial dangers with which horse-racing was beginning to be linked.

\section{Racing to the North}

Jony's absence in the Osborne manuscript may be strictly a consequence of the playwright's desire, or that of another person involved in the transmission of The Humorous Magistrate, to stabilize Wild's economic status and render him a more virtuous and worthy suitor. Yet, even as it is possible that the removal of the one character was solely aimed at redeeming the other, the prospect that multiple revisions and differences in two extant manuscripts of The Humorous Magistrate were all part of an attempt to reform a man who is not a primary protagonist in the play seems rather unlikely. Indeed, to account for the omission of the northern or Scottish horseman Jony by taking recourse to his master's dramatic characterization alone not only fails to account for all of the material that disappears from one version to the next - Tib's speeches, for instance - but also ascribes changes to the work to a more narrow sense of moral propriety than seems to be in operation elsewhere in the play. And of course, we must acknowledge once again that horse-racing itself was far from universally condemned; according to one early historian, 'even the puritans ... relaxed in favour of the race-course. 59

Furthermore, although ethics and social decorum would have been important in any gentry or noble household in the shires throughout the seventeenth century, such cultural forces did not exist in isolation from other kinds of political factors and so it is worth examining the enterprise of horse-racing beyond its moral implications and domestic import in the late 1630s. In fact, horse-matches were not merely sites that enabled petty crimes, the loss of aristocratic fortune, and less permanent inversions of social hierarchies. They were, at some moments in England's history, the sites of high treason.

Perhaps the most famous incident involved the aforementioned earl of Holland, the dedicatee of Shirley's Hyde Park and the official keeper of the actual park. The earl would ultimately be deprived of that title as well as his earldom, the Holland estate, and his life when parliament ordered his execution in 1648. His crime was organizing troops against them on behalf of Charles I; he had apparently planned to do so by using the park to muster an army in the guise of gathering horses to race. According to H.E. Malden, 
When Holland's ill-contrived royalist rising of 1648 took place at Kingston, the original plan had included a muster of adherents, as for a horse race, on Banstead Downs. Rumour was rife at the time of such an assembly being formed, and that Holland had marched thither from Kingston. But in fact he had marched to Dorking, and Major Audeley, who was on his track, went over Banstead Downs without finding him or the assembly. The rising had in fact exploded prematurely. ${ }^{60}$

Despite its apparent failure, Holland's infamous attempt and subsequent punishment would lead the council of state to prohibit races in England after 1649. The fears of another such plot would also inflect, if not outright motivate, Cromwell's proclamations prohibiting races in the 1650s. The first of these proclamations was printed in 1654, warning those who would 'minister an Opportunity to give any Disturbance to the Publique Peace' with 'secret and mischievous Plots':

the Protector being informed that several horse-Races are appointment in divers parts of this commonwealth, and considering how great a concourse of people do usually frequent such meetings, and the evil Use made thereof by such illdisposed persons as watch for opportunities to raise New Troubles; for the better preventing of the Evils which may arise thereby to the people of this commonwealth, his highness by the advice of his Council, Doth hereby prohibit and forbid all horse-races, and all meetings any persons whatsoever upon pretense or colour of any horse-races, in any place within England or Wales, for the space of six Moneths. ${ }^{61}$

Notably, the proclamation prohibits not just racing but any 'pretense or colour' of it; while the lord protector continued to maintain the racing stock in the royal stables and apparently appreciated the horses themselves, the gathering of men on horseback for any purpose was suspicious and posed an implicit threat to the commonwealth. Indeed, Cromwell issued additional proclamations along the same lines in the following year and again in 1658 . The geographical purview of the proclamations limits such activities only in England and Wales, presumably because in the two years prior, his wars had so significantly reduced Ireland and Scotland that neither country had the resources to field a resistance army.

Of course, these developments after the execution of Charles I transpired more than a decade after the transmission of the Osborne The Humorous 
Magistrate; as such, they cannot be said to have any direct bearing on the changes that were made therein. Nonetheless, they provide a broader picture of a phenomenon that had even earlier roots. In several cases prior to the execution of Charles I, horse-racing and its business relations were specifically understood as a threat to England's government and its relationship with Scotland. In 1647, the year before the earl of Holland sealed his fate, state papers from commissioners in Scotland detail Caroline officials' fears of a surprise attack on Berwick, an English garrison town on the border that had a long history of changing from Scottish to English hands. Addressing members of English commissioners there, these men warned 'of many great Delinquents in the North of England, who (we have good Reason to believe) are projecting Mischief, and none more probable at this Time than some Enterprizes to interrupt the Union and brotherly Agreement which (we hope) will ever be betwixt these Kingdoms of England and Scotland'. Accordingly, they implored them 'to give a strict Charge to the Watch of your Town', a vigilance that required them 'not to permit any Soldiers' into Berwick, and 'that [they] would have especial Care of it at the Time of this Horse Race near you'. ${ }^{62}$

Such races in and near Scotland had as long, if not longer, a history of regulated and regular meetings for public racing in the burghs as locations in the south and middle of England. James I's legislation in the 1620s mitigated some of the consequences enabled by high betting prospects and, according to Burnett, some of the morally suspect practices that took place at English races 'were largely absent in Scotland'. ${ }^{63}$ Yet he also notes that racing in Scotland was not without significant amounts of controversy; sometimes racing was prohibited because spectators and participants alike 'used it as an opportunity for settling personal grievances'; in fact, 'Record of races usually survives because something other than racing happened at them, as when Border reivers met at a race to plan a raid, or what a spectator was shot at Ayr in 1576.64

One instance that had some larger implications for Anglo-Scottish relations involves the imprisonment and subsequent liberation of William Armstrong, a Scottish borderer whose countrymen famously disgraced the English deputy in charge of securing him in Carlisle Castle. 'Kinmont Willie' was immortalized in a popular ballad that depicts a deadly and well-orchestrated prison-break enabled by the country's swiftest riders. This 'Will of Kinmoth' also appears in less sensational records. A letter from the Scottish commissioner dated April 1585, for instance, places him 'at a horse race in 
Liddesdale' and also on the back of 'Gray Carver', a horse of Lancelot Carlton's', the same month of his capture by English riders at the behest of Lord Scroop. ${ }^{65}$ Shortly thereafter, Scroop himself had confirmed that the incidents in the ballad had actually transpired in the manner it depicts. He wrote to the privy council of 'the proude attempte' which the Scots have made on this her Majesty's castle and chief strength here', explaining that they 'carried him awaye, and in their discoverie by the watch, lefte for deade two of the watchmen, hurt a servante of myne one of Kynmontes keperes, and were issued againe oute of the posterne before ... resistance coulde be made'. ${ }^{66}$ Still smarting from the incident more than a decade later, he invoked 'the surprise of this castle and loosing Kinmont out of it' in a letter to Henry Lee and explained that it had all been planned 'at a horse race long before'. ${ }^{67}$

As Elia Williamson notes, in 1608 the Scottish privy council banned racing at Peebles 'for fear of trouble from the "privat grudeus"' that might surface there; she also suggests that races were held regularly in many burghs in Scotland until 1638, when records become notably sparse. ${ }^{68}$ Most compelling for our study of the Arbury The Humorous Magistrate is the prospect of a cancelled horse-match planned at Berwick that year, as it falls between the dates that scholars claim for the production of the versions of the two extant manuscripts. Writing from Newcastle in 1639, the same year Charles I attempted to counter the Scots' resistance to the Anglican prayerbook with military force, Sir Jacob Astley explained that '[after] Hearing of their intended horse race at Berwick, I desired Lord Clifford to write to the mayor to forbid it'; Lord Clifford confirmed in response that he 'sent away at night, on Saturday, to the mayor of Berwick, who has prohibited the horse match intended, and (as I gather) made to the same pernicious end you conceived'. The major himself, William Fenwick, also wrote to Astley, thanking him 'for [his] respect to this poor town' and acknowledging his shared suspicions about the motives for holding a race: 'The Scots for anything I can perceive are still insolent in their ways, but they desisted from their horse-race in our bounds. ${ }^{69}$

Other records from the same year make clear that Charles I was mindful of impending war with Scotland, and horses and horse-racing were problematic for the king, not just because the Scots might exploit them for 'pernicious ends'. Earlier in his reign, his advisors had worried that 'horse-racing was making too much progress and operating to the detriment of the general breed of horses in the kingdom', and noted 'the deficiency of good and stout horses for its defence, on account of the strong addiction which the nation had to racing and hunting horses, which, for the sake of swiftness, were of a 
lighter and weaker mould' 70 The king himself admitted as much in March of 1638 , and also expressed concern that horses were so in demand for racing then that members of the nobility, who were required to own horses and arms for shire defense according to muster statutes, were unable to buy them for that purpose at reasonable rates. In a proclamation from Whitehall, his lord marshal invoked the campaign against Scotland and the aristocrats 'who are to attend and serve His Majesty in the Expedition now in hand' and warned those selling horses at an upcoming fair 'to have especial care, that no Horse-Courser, nor any for them, shall be permitted to buy any Horses within that Fair, or Town, and the Precincts and Liberties thereof, until the last day of the said Fair, to the end the Nobility and Gentry having such number of Horses for his Majesty's service..$^{71}$

As these examples demonstrate, the conflict over the Anglican liturgy between 1636 and 1640 made both Scotland and the enterprise of horseracing politically fraught subjects in coinciding as well as separate ways. Any of the various intersections between the two could have made a character like Jony troublesome, even if his national origins were as ambiguous then as they now appear to modern readers. Indeed, Jony does not need to be Scottish for his dialect to signal a cultural difference that, even within a private household, might have been uncomfortably provocative.

\section{Conclusion}

In discussing the multiple factors that might account for Jony's absence from the Osborne manuscript, I have tried to offer explanations that are complex and convincing irrespective of the identity of the agent or agents that were responsible for the revisions. In concluding, however, I will briefly note how my discussion of these factors contributes to recent scholarly work on the manuscripts' authorship; it complements, in particular, the persuasive case for John Newdigate III presented by Johnstone and Inglis in this special issue. In her study of the Newdigate family, Vivienne Larminie describes John III as having 'a passion for racing. ${ }^{72}$ In addition to his 'regular attend[ance]' at the matches in Brackley, he entered a horse there in 1637 - the same year Shirley's Hyde Park appeared in print — and 'paid his jockey the princely sum of $£ 3 .{ }^{73}$ Although the Osborne project researchers did not find a quarto of Shirley's racing play amongst the substantial holdings in the Arbury Hall library inventory of 1858, Larminie does note that the Newdigate brothers' account book records the purchase of two copies of Gervase Markham's Book 
of Horsemanship, as well as the acquisition of Shirley's masque The Triumph of Peace (1633). His account books also indicate that he saw a performance of The Gamester (1633), also by Shirley, in 1634 at Blackfriars. ${ }^{74}$

Taken along with these biographical details, the assertions I have made here about The Humorous Magistrate's relationship to Hyde Park may also provide additional confirmation for the proposed dates for the Arbury manuscript's composition or transcription. John Newdigate's apparent familiarity with Shirley's work increases the likelihood that Jony's catalogue of horse names derives from the racing song in Hyde Park; the period between the play's licensing for performance in 1632 and its entrance into the Stationers' Register in 1637 coincides exactly with the range of years identified by Kidnie, Polito, and Windle for the composition of the Arbury version. ${ }^{75}$ Even without compelling evidence of the play's authorship or year of composition, the differences between the two manuscripts strongly suggest that the playwrights who wrote drama for non-commercial contexts composed and revised their work under some of the same political pressures that constrained their professional counterparts - even as their dramatic works were produced for smaller audiences and more homogenous social groups.

If we are tempted to believe that subjects in the Midlands were too removed geographically from London or Scotland to be concerned with the crown's rising tensions with Scotland or invested enough to alter a household manuscript that was clearly intended to entertain, a work I mentioned earlier in this essay, North's Forest of Varieties, provides a useful corrective to such assumptions. Printed in 1645 , but written several years earlier, this eclectic mix of jocular prose and more serious verse includes not only the poem in which a lord puts a jockey in his place, but also its author's musings on the subject of 'the Common Prayer Book ... [and] how the Scots esteem it'. North, a gentleman from Hertfordshire and Cambridge, apparently saw fit to assert a jockey's unambiguous inferiority in the same text in which he discusses 'the scandall [of] these late times' ${ }^{76}$

In his short treatise on the matter, North figures Scottish grievances and Charles's response to them with studied ambivalence; his writing, a mixture of simple country recreation and complex political commentary, provides some evidence that an aristocrat in the 1630s could have, concomitantly, an investment in literary aesthetics, an interest in preserving hierarchy in social interactions within an estate, and an awareness of urgent issues affecting the entire realm. The Arbury playwright seems to have given us something of the same sort of evidence in his apparent revisions to The Humorous Magistrate. 
Rather than a reflection of national and regional tensions alone, Jony's omission from the Osborne copy may very well be a consequence of multiple, overlapping factors. His presence and absence allows us to imagine the pleasures and pressures that occupied those in the country and more particularly suggests the likelihood that political issues necessarily pervaded the lives of those who made their homes there; the horseman from the north would have tied the household and its local recreation to the border — and to the not-sodistant sites of centralized government, civil conflict, and inter-national war. If the Arbury playwright was not writing for the Caroline playhouse when he wrote or revised the play, his work was nonetheless part of a communal enterprise; the play itself must have been, like the history of which it was part, always, inevitably, subject to change.

\section{Notes}

1 T.H. Howard Hill is responsible for supplying the play's title. Discussions of the two versions appear in Mary Polito and Jean-Sébastien Windle, "You See the Times are Dangerous": the Political and Theatrical Situation of The Humorous Magistrate', Early Theatre 12.1 (2009), and Margaret Jane Kidnie, 'Near Neighbours: Another Seventeenth-Century Manuscript of The Humorous Magistrate', English Manuscript Studies, 1100-1700 13 (2007).

2 Polito and Windle, "You see the times are dangerous", 96.

3 Ibid, 96 and n 11; these dates accord with Kidnie's assessments of hands and watermarks in 'Near Neighbours', 5, 7.

4 All citations from Shakespeare's works derive from The Riverside Shakespeare, second edition, ed. G. Blakemore Evans and J.J.M. Tobin (Boston, 1997).

5 See Paula Blank, Broken English: Dialects and the Politics of Language in Renaissance Writings (London, 1996), 111-12.

6 The standard argument, advanced by F.J. Harries in Shakespeare and the Scots (Edinburgh, 1932), is that Jamy (along with the Irish MacMorris) was an addition made to the 1623 folio. Keith Brown and Andrew Gurr have challenged this assessment, the former arguing that only Jamy was a late addition; see 'Why Captain Jamy in Henry V', Archiv fur das Studium der Neueren Sprachen und Literaturen 226 (1989), 365-73, and 'Historical Context and Henry V', Cahiers Elisabéthains: Late Medieval and Renaissance Studies 29 (1986), 77-81, respectively.

7 These meetings include the 2009 meeting of the Shakespeare Association of America and a workshop at the University of Calgary entitled 'New Directions in Medieval 
and Renaissance Drama'; this essay comes primarily out of the former. I am grateful for the comments and feedback I received from those present at each meeting, as well as from the readers for Early Theatre. I am particularly grateful for assistance from Margaret Jane Kidnie and Mary Polito, who provided copies of both manuscripts and a wealth of other information, and for editorial assistance from Amy Scott.

$8 O E D$, s.v. 'ken'. According to senses 11.a and b, the usage is 'now chiefly' Scottish. The Dictionary of the Scots Language, which includes the Dictionary of the Older Scottish Tongue (DOST), confirms the information supplied by the OED. See The Dictionary of the Scots Language, s.v. 'ken, v.', http://www .dsl.ac.uk/.

9 See the Preface and Introduction in Wales, Northern English (Cambridge, 2006).

10 James Miller, Swords for Hire: The Scottish Mercenary (Edinburgh, 2007), 71-2.

11 The Jacobean succession and attempted Act of Union may be responsible for the apparent evasiveness on this front; James, of course, famously declared the lands near the Scottish border would be renamed 'the Middle shires', purporting to erase the enmity and national boundaries by mere proclamation. The epistles preceding equine-related manuals often identify the nation as 'Britain', rather than England, a designation that perhaps obviated the need for referencing England and Scotland as isolated or separable regions when describing specific practices unique to each. In De la Grey's The Compleat Horseman (London, 1639), for instance, he refers to 'our Kingdome' - a place he describes on the same page as 'our iland of Great Britaine', EEBO, b2v. His use of 'Great Britaine' may owe less to James I and William Camden for popularizing the concept than to the fact that his epistolary dedicatees were Scots.

12 OED, s.v. 'swipper'. The Dictionary of the Scots Language does not record the use of 'swipper' until the eighteenth century, s.v. 'swipper, adj.', http://www.dsl.ac.uk/ index.html.

13 Blank, Broken English, 153.

14 Ibid, 159.

15 María Fuencisla García-Bermejo Giner, 'The Northern/Scottish Dialect in Nathaniel Woodes' A Conflict of Conscience (1581)', Sederi 9 (1998), 9-21.

16 On debates over these terms, see Marina Dossena, Scotticisms (Edinburgh, 2005), especially vii-ix and $8-17$.

17 Anneli Meurman-Solin, 'Letters as Source of Data for Reconstructing Early Spoken Scots', Irma Taavitsainen, Gunnel Mechers, Påivi Pahta (eds), Writing in Nonstandard English (Philadelphia, 2000), 309. 
18 Gerald Porter, 'The Ideology of Misrepresentation: Scots in English Broadsides', Writing in Nonstandard English (Philadelphia, 1999), 365.

19 Ibid, 365.

20 Ibid, 366. Fuencisla Garcia-Bermejo Giner also suggests that contemporary English audiences would have been unable to distinguish between non-standard variants; see 'The Northern/Scottish Dialect', 9.

21 Citations from the manuscript versions are from the Malone Society Editions, Margaret Jane Kidnie (ed.), The Humorous Magistrate (Arbury) (Manchester, 2011) and Jacqueline Jenkins and Mary Polito (eds), The Humorous Magistrate (Osborne) (Manchester, 2011).

22 Katie Wales, Northern English (Cambridge, 2006), 79.

23 Writing on the absence of such dialect in Shakespeare's most Scottish play, Chris Highley argues that 'the spectacle of Scottish characters on the London stage in 1606 using Shakespeare's standard East Midland dialect of English may have performed a kind of ideological work that has gone unnoticed by recent critics preoccupied with the play's treatment of conspicuous topical issues like regicide and resistance'. See 'The Place of Scots in the Scottish Play: Macbeth and the politics of language', Willy Maley and Andrew Murphy (eds), Shakespeare and Scotland (Manchester, 2005), 57. This contention applies as well to the dialect-free but stereotypically boastful Scot, Douglas, in parts one and two of Henry IV.

24 Citations derive from The Valiant Scot, by J.W.: A Critical Edition, ed. George F. Byers (New York, 1980) and John Tatham, The Scots Figgaries (London, 1652), Literature Online (Cambridge: Chadwyck-Healey, 1994) http://gateway.proquest.com .ezproxy.cul.columbia.edu/openurl?ctx_ver=Z39.88-2003\&xri:pqil:res_ver $=0.2 \&$ res_id=xri:lion-us\&rft_id=xri:lion:ft:dr:Z000125191:0.

25 Cited from Martin Butler (ed.), The Selected Plays of Ben Jonson (Cambridge, 1989).

26 Wales also discusses the 'rather strange conglomerate [of] Northern/Scots dialect in his unfinished play The Sad Shepherd', Northern English, 77. See also Blank, Broken English, 163.

27 Cited from Richard Herne Shepherd (ed.), The Dramatic Works of Richard Brome (New York, 1966). This edition does not have scene divisions.

28 Word counts are calculated from transcriptions available in Literature Online (Cambridge: Chadwyck-Healey, 1994). 220 of Constance's 1367 words appear in nonstandard forms or spellings consistent with the speeches of other characters; by contrast, Peggie's speeches, totaling 399 words, contain 190 dialect forms. In the 1623 folio version of Henry $V$, twenty-six of Jamy's fifty-two words are dialect forms.

29 Porter, 'Ideology of Misrepresentation', 370. 
30 On this play's treatment of Scottish characters, see Susan Wiseman, Drama and Politics in the English Civil War (Cambridge, 1998), 171-2.

31 See, for instance, Christopher Highley, Shakespeare, Spenser, and the Crisis in Ireland (Cambridge, 1997), 146.

32 EEBO, b2v.

33 In Captain Luckless: James, First Duke of Hamilton, 1606-1649 (Edinburgh, 1975), Hillary L. Rubenstein observes that the marquis had 'never once demonstrated the slightest military talent' (28). For a more recent biographical account, see John J. Scally, 'Hamilton, James, first duke of Hamilton (1606-1649)', DNB (2005). Hamilton's own papers also provide interesting insight into his love of country (or lack thereof); he wrote to Charles in 1639 with the profession that 'soe porefully doe I hate this rebellious nation, as I had rather lose my liffe then not in my oune particuler be reuenged on them'. 'Hamilton to Charles I, 26 May 1639', Samuel Rawson Gardiner (ed.), The Hamilton Papers: Being Selections from Original Letters in the Possession of His Grace the Duke of Hamilton and Brandon, Relating to the Years 1638-1650 (Westminster, 1880), 87.

34 Some accounts describe him confronting his own mother at the border; see William Douglas Hamilton (ed.), Calendar of State Papers, Domestic Series, of the Reign of Charles I, 1639 (London, 1873), 145-6, 282.

35 According to the narrators of Vox Borealis, or the Northern Discovery (London, 1641), $E E B O, \mathrm{BR}$, Caroline authorities fined and jailed a group of players in reaction to surreptitious performances of 'the Valiant Scot, which they Played five dayes with great applause, which vext the Bishops worse than the other, in so much as they were forbidden Playing it any more; and some of them prohibited ever playing again'.

36 The character of Spruce is central to both versions of the play, though these versions deploy different spellings of his name. I use the Arbury's spelling of 'Spruse' rather than the Osborne's 'Spruce', here and throughout this essay, since the lines attributed to him in quotations derive almost exclusively from this version of the play.

37 The $O E D$ defines the adjective in terms of the primary sense of the noun 'clan' as 'A number of persons claiming descent from a common ancestor, and associated together', which is 'applied to those of the Highlands of Scotland; extended also to Lowland Scottish families, esp. in the Border country, where a somewhat similar social system prevailed' $O E D$, s.v. 'clan'.

38 The designation is one supplied in the materials authored by the group working on the manuscripts; see 'University of Calgary Osborne Project'.

39 In this play, Jocky is both the name of the Scottish beggar and con-artist and a more generic Scot invoked in a raucous ballad denouncing Scottish covenanters that the play's English heroes sing in the play's final act. 
40 The Humorous Magistrate also depicts the domestic and educational pastimes of a country estate's young woman in a manner that resonates with Shrew: like Bianca and Katherina, Thrifty's daughter Constance has a music master teaching her to play the lute. Unlike Katherina, however, Constance does not abuse her teacher with the instrument.

41 Elspeth Graham, 'Reading, Writing and Riding Horses in Early Modern England: James Shirley's Hyde Park (1632) and Gervase Markham's Cavelarice (1607)', Erica Fudge (ed.), Renaissance Beasts: Of Animals, Humans, and Other Wonderful Creatures (Urbana-Champaign, 2004), 118.

42 James Shirley, Hide Parke a Comedie, as it vvas Presented by her Majesties Servants, at the Private House in Drury Lane (London, 1637). Shirley may be the original author of the ditty, but the tune, if not the song, had a long afterlife in ballads printed throughout the seventeenth century; many title-pages, like that of $A$ New Ditty of a Lover, Tost Hither and Th[i]ther, that Cannot Speake his Mind When They are Together (London, 1640), indicate that they are to be sung 'to the tune of Hide Park'. The same horse names also appear in a manuscript of poetry by William Basse (1602-1653). In A Bibliographical and Critical Account of the Rarest Books in the English Language (New York, 1837), John Payne Collier describes a poem by Basse that, like the Arbury play, 'mentions the names of many favourites of that day, Crop-ear, Friskin, Kill-deer, Herring, Pegabrig', but he does not reprint the poem or suggest a likely date for it. In his edition of Basse's poetry, The Poetical Works Of William Basse, (London, 1893), R. Warwick Bond invokes Collier's description with some frustration, asking plaintively, 'What were these "other poems", and where had Collier seen them?' (162). The convention of listing the names of racing steeds features in earlier texts, such as Joseph Hall's Virgidemiarum (London, 1599), and became more widespread in the later seventeenth and eighteenth centuries, with works such as Thomas D'urfey's The Call to the Races at New-Market (London, 1685).

43 On the Arbury's reference to Hamlet, see Polito and Windle, "You see the times are dangerous", 103.

44 According to Roger Longrigg in The History of Horse Racing (London, 1972), James's enthusiasm for racing, as well as his patronage, grew out of his love for hunting; as Longrigg describes it, his 'establishment of Newmarket as "headquarters" for the sport was almost accidental' (39). See also Horse-Racing: Its History and Early Records of the Principal and other Race Meetings (London, 1863), 41-3. Neither the front matter nor library catalogues provide information regarding the author of the latter study. 
45 The most comprehensive account of racing during the reign of Charles I and of his patronage is J.P. Hore, The History of Newmarket: And the Annals of the Turf, 3 vols (London, 1886), 2.1-217; see also Longrigg, The History of Horse Racing, 39-45.

46 Graham, 'Reading, Writing and Riding Horses', 21. This notion also surfaces in county histories, works that are not nominally about Shirley or his play; see, for example, A History of the County of Middlesex: Volume 2: Ashford, East Bedfont with Hatton, Feltham, Hampton with Hampton Wick, Hanworth, Laleham, 4 vols (Littleton, 1911), 2.223-51; and J.P. Hore, The History of Newmarket, 2.143-7.

47 Graham, 'Reading, Writing and Riding Horses', 23.

48 Two more half-lines here have been smudged out in the manuscript that seem incomplete; they are nonetheless suggestive and in keeping with my sense of the passage overall. They read: ' $\&$ be a higher man then / too then whan he is a]' (1272).

49 OED, s.v. 'Stirrup, n.'.

50 Richard Brome, The Antipodes a Comedie. Acted in the Yeare 1638 (1640), EEBO, C2r.

51 Thomas Dekker, The Owles Almanacke Prognosticating Many Strange Accidents which Shall Happen to this Kingdome of Great Britaine this Yeere (1618), EEBO, 51. The second of the three quoted phrases comes from a marginal gloss on the same page, the third from the title-page.

52 OED, s.v. 'Jocky, n.'. The OED's earliest listed example of the horse-manager is from The Antipodes; it also appears, however, in William Camden's Britannia, printed in 1637 but penned around 1566.

53 Dudley North, A Forest of Varieties (1645), ЕЕво, 92.

54 Eila Williamson describes a court case before the Scottish privy council that hints at the threat that 'new men' posed to their social superiors by way of their success at the races. A merchant named Barclay was attacked along with his horse on their way to a match; the man he accused of planning the attack was a wealthier competitor. See 'Horse-Racing in Scotland in the Sixteenth and earlier Seventeenth Centuries: Peebles and Beyond', Review of Scottish Culture 14 (2001-2002), 31-42, especially 38-9.

55 Robert Burton, The Anatomy of Melancholy VVhat it Is (London, 1621), EEBO, 338.

56 Quoted in John Burnett, Riot, Revelry, and Rout: Sport in Lowland Scotland before 1860 (East Lothian, 2000), 41.

57 Ibid, 103.

58 Nevvs from Hide-Parke: or A very merry strange passage which happened betwixt a north-country gentleman, and a very gaudy gallant lady of pleasure (London, 16401643). ЕЕво. This ballad is a single page and therefore unpaginated.

59 Horse-Racing: Its History and Early Records, 55. As Longrigg notes in The History of Horse Racing, even men praised for their 'piety and probity' (44) could make a 
I76 Vimala C. Pasupathi

regular practice of betting on horses; indeed, sometimes horses were backed by the clergy (31).

60 'Parishes: Banstead', A History of the County of Surrey: Volume 3 (1911), 252-62, http://www.british-history.ac.uk/report.aspx?compid=42963\&strquery=bansted 1648.

61 An Ordinance Prohibiting Horse-Races for Six Moneths (London, 1654), EEBO.

62 'House of Lords Journal Volume 10: 21 March 1648', Journal of the House of Lords: volume 10: 1648-1649 (1767-1830), 124-9, http://www.british-history.ac.uk/.

63 Burnett, Riot, Revelry, and Rout, 22.

64 Ibid, 21.

65 'Border Papers volume 1: April 1585', Calendar of Border Papers: volume 1: 1560-95 (1894), 177-81, http://www.british-history.ac.uk.

66 Ibid.

67 'Border Papers volume 2: April 1596', Calendar of Border Papers: volume 2: 15951603 (1896), 118-28, http://www.british-history.ac.uk.

68 Williamson, 'Horse-Racing in Scotland', 32-6. Records for races commence after 1640, when the bishops' wars had concluded.

69 'Charles I - volume 414: March 1-20, 1639', Calendar of State Papers Domestic: Charles I, 1638-9 (1871), 522-88, http://www.british-history.ac.uk.

70 Horse-Racing: Its History and Early Records, 52.

71 John Rushworth, Historical Collections. The Second Part (London, 1721), 838.

72 Vivienne Larminie, Wealth, Kinship, and Culture: The 17th-Century Newdigates of Arbury and Their World (Rochester, 1995), 16,

73 Ibid, 71, 168.

74 Ibid, 199-202.

75 Polito and Windle, "You See the Times are Dangerous", 96.

76 North, A Forest of Varieties, EEBO, 236. 